\title{
Ion concentration homeostasis and the regulation of neuronal firing activity: the role of cation-chloride cotransporters
}

\author{
Alexander O Komendantov ${ }^{1}$, John R Cressman $\mathrm{Jr}^{1,2}$, Ernest Barreto ${ }^{1,2^{*}}$ \\ From Nineteenth Annual Computational Neuroscience Meeting: CNS*2010 \\ San Antonio, TX, USA. 24-30 July 2010
}

Ion concentration homeostasis is essential for normal neuronal functions and its changes can underlie different pathological conditions including seizures. However the mechanisms of these processes are poorly understood. Studying the dynamical and biophysical mechanisms of regulation of neuronal intra- and extra-cellular ion concentrations is important for the development of methods to treat neurological disorders.

We constructed a conductance-based neuron model [1], which includes dynamic variables representing the intracellular $\mathrm{Na}^{+}$and extracellular $\mathrm{K}^{+}$concentrations.

In this model, the $\mathrm{Na}^{+}$and $\mathrm{K}^{+}$concentrations are affected by sodium, potassium, and leak currents, $\mathrm{Na}^{+}-\mathrm{K}^{+}$pump current, an uptake of potassium ions by glial current, and potassium diffusion. The leak current is represented by the sum of sodium, potassium and chloride leaks. The concentrations couple to the membrane voltage equations via the Nernst reversal potentials. The model also contains a voltage-gated calcium current and a simple model for the intracellular $\mathrm{Ca}^{2+}$ dynamics. The model produces slow and large-amplitude oscillations in ion concentrations similar to oscillations observable during seizures or seizure-like activity in vitro.

We extended this model to include $\mathrm{Cl}^{-}$concentration dynamics. In the nervous system, the intracellular $\mathrm{Cl}^{-}$ ion concentration $\left.\left(\mathrm{Cl}^{-}\right]_{\mathrm{i}}\right)$ determines the strength and polarity of GABAergic neurotransmission. This concentration is maintained by the activity of cation-chloride cotransporters (CCCs). We explored in a computational study the roles of two CCCs (the NA-K-2Cl cotransporter, $\mathrm{NKCC} 1$, and the $\mathrm{K}-\mathrm{Cl}$ cotransporter, $\mathrm{KCC} 2$ ) in ion

\footnotetext{
* Correspondence: ebarreto@gmu.edu

${ }^{1}$ Krasnow Institute for Advanced Study, George Mason University, Fairfax, VA, 22030, USA
}

concentration homeostasis and in the generation of pathological oscillatory activity in neurons.

Our computational studies show that reciprocal changes in the expression of NKCC1 (which elevates $[\mathrm{Cl}]_{\mathrm{i}}$ ) and $\mathrm{KCC} 2$ (which decreases $\left[\mathrm{Cl}^{-}\right]_{\mathrm{i}}$ ) can change $\mathrm{Cl}^{-}$reversal potential $\left(\mathrm{E}_{\mathrm{Cl}}\right)$ and significantly alter the effects of $G_{A B A}$ receptor $\left(G_{A B A} R\right)$ mediated inhibitory input. Under certain circumstances, this can evoke or prevent seizure-like activity, and we investigate dynamical and biophysical mechanisms of these phenomena. The model suggests that regulatory abilities of CCCs are increased with increasing $\mathrm{GABA}_{\mathrm{A}}$ Rs activation. Both simulated elevation of concentration of extracellular potassium ion $\left(\left[\mathrm{K}^{+}\right]_{0, \infty}\right)$ and NA-K-2Cl cotransporter activity promote seizure-like activity. Our studies show that developmental regulation of expression of NKCC1 and $\mathrm{KCC} 2$, in conjunction with concentration dynamics, can alter $\mathrm{Cl}^{-}$electrochemical gradient and strength and polarity of $\mathrm{GABA}_{\mathrm{A}}$ neurotransmission.

The computational studies corroborate that CCCs are potential targets for treatment of neurological diseases, which involve dysfunctions in intracellular ion concentration homeostasis.

\section{Acknowledgements}

This work was funded by NIH Grant 5R01MH079502 (EB)

\section{Author details}

'Krasnow Institute for Advanced Study, George Mason University, Fairfax, VA, 22030, USA. ²Department of Physics and Astronomy, George Mason University, Fairfax, VA, 22030, USA.

Published: 20 July 2010 


\section{Reference}

1. Cressman JR Jr, Ullah G, Ziburkus J, Schiff SJ, Barreto E: The influence of sodium and potassium dynamics on excitability, seizures, and the stability of persistent states: I. Single neuron dynamics. J Comput Neurosci 2009, 26(2):159-170.

doi:10.1186/1471-2202-11-S1-P27

Cite this article as: Komendantov et al:: Ion concentration homeostasis and the regulation of neuronal firing activity: the role of cation-chloride cotransporters. BMC Neuroscience 2010 11(Suppl 1):P27.

Submit your next manuscript to BioMed Central and take full advantage of:

- Convenient online submission

- Thorough peer review

- No space constraints or color figure charges

- Immediate publication on acceptance

- Inclusion in PubMed, CAS, Scopus and Google Scholar

- Research which is freely available for redistribution

Submit your manuscript at www.biomedcentral.com/submit

() Biomed Central 